\title{
THE RE-EMERGENCE OF AMERICAN VISCERAL LEISHMANIASIS IN AN OLD FOCUS IN VENEZUELA: PRESENT SITUATION OF HUMAN AND CANINE INFECTIONS
}

\author{
DELGADO O.*. FELICIANGELI M.D.********, GOMEZ B. ${ }^{* *}$, ALVARADO J.***, GARCIA L.**** \& BELLO C.****
}

\section{Summary :}

The report of a new autochthonous case of human American Visceral Leishmaniasis (AVL) in 1992 in the village of Guayabita, Aragua Stale, Venezuela $\left(10^{\circ} 16^{\prime} \mathrm{N}, 67^{\circ} 28^{\prime} \mathrm{W} ; 500 \mathrm{~m}\right.$ asl), led us to undertake an epidemiological study in this locality. A demographic survey was conducted using a structured questionnaire in which dara was collected regarding sex, age, occupation, length of residence in the area and migratory history A leishmanin skin test (LST) was applied and samples of venous blood for counter immunoelectrophoresis (CIEP) and

immunofluorescent antibodies (IFAT) lests were drawn. The prevalence of positive LST was $11.4 \%$. The positivity was highest among males and increased with age. Young males seemed to be more exposed to infection than females. Since occupation per se did not seem to account for this association, it may be explained as a gender-associated behavior, leading to different degrees of exposure to sand flies. The canine population was also screened for leishmanial infection. One dog was shown to be parasitologically infected with Leishmania sp. Four out of 71 dogs $15.6 \%$ were positive for FG, CIEP, IFAT and Western Blot and $11(15.5 \%)$ were positive for CIEP. These results suggest that after almost 30 years of epidemiological silence, American visceral leishmaniasis has re-emerged in this focus.

KEY WORDS : AVL, human visceral leishmaniasis, canine visceral leishmaniasis, re-emergence, Venezuela

\section{INTRODUCTION}

1 he first case of human American visceral leishmaniasis (AVL) in Venezuela was reported by Martinez Niochet \& Pons in 1941 from Zulia

\footnotetext{
* Instituto de Medicina Tropical, Universidad Central de Venezuela Caracas, Venezuela.

* Universidad de Carabobo, Facultad de Ciencias de la Salud, BIOMED, Maracay, Venezuela.

*** Servicio de Dermatología Sanitaria, Hospital Central de Maracay, Venezuela.

"*** Instituto de Biomedicina, Universidad Central de Venezuela, Caracas, Venezuela.

**s** Instituto de Investigaciones Veterinarias, Maracay, Venezuela. ****** Escuela de Malariología y Saneamiento Ambiental "Dr. Arnoldo Gabaldón " Maracay, Venezuela.

Correspondence: M. Dora Feliciangeli, Apartado 4873, Maracay, Venezuela.

Tel. : ++5843419997- Fax: ++5843332532

e-mail: mdora@telcel.net.ve
}

Résumé : RÉ-ÉMERGENCE DE LA LEISHMANIOSE VISCÉRALE AMÉRICAINE DANS UN FOYER ANCIEN DU CENTRE-NORD DU VÉNÉZUELA : SITUATION ACTUELLE DES INFECTIONS HUMAINES ET CANINES

La détection en 1992 d'un nouveau cas autochtone de leishmaniose viscérale dans le village de Guayabita, Ėat Aragua, Vénézuela $110^{\circ} 16^{\prime} \mathrm{N}, 67^{\circ} 28^{\prime} \mathrm{O} ; 500 \mathrm{ml}$, nous a poussé à entreprendre une étude épidémiologique dans cette localité. Une enquête démographique a été realisée pour rassembler les données sur le sexe, l'âge, l'a profession, le temps de résidence dans la localité el l'histoire migratoire des habitants. L'enquête inmunologique a été faite par intradermo-réaction (IDR), électrosynérèse (CIEP) et immunofluorescence indirecte (IFI). La prévalence globale par IDR a été de 11,4\%. La positivité est plus élevée parmi les sujets de sexe masculin et elle augmente avec l'âge. Les hommes jeunes semblent plus exposés au risque d'infection que les femmes. Puisque l'occupation per se n'est pas en relation avec cette association, ce résultat pourrait être interprété comme une conséquence du comportement masculin qui détermine une exposition différente aux phlébotomes. La population canine a été également éfudiée. Parmi 71 chiens, quatre $(5,6 \%)$ ont éré rrouvés positits par formolgélification (FG), CIEP, IFI et Western Blot (WB). De plus, 11 (15,5\%) étaient positifs pour CIEP. Ces résultals suggèrent qu'après 30 années de silence épidémiologique, la leishmaniose viscérale a émergé đa nouveau dans ce foyer.

MOTS CIÉS : leishmaniose viscérale humaine, leishmaniose viscérale canine, réémergence, Vénézuela.

State, in the west of the country. Intensive work on the epidemiology of this disease has been carried out until the 70s ( Pifano 1954; Pifano \& Romero, 1964a, 1964b; Amaral et al., 1961a, 1961b, 1961c; Torrealba et al., 1961, Torrealba 1970). It was determined that American visceral leishmaniasis was endemic in the rural areas, presented sporadic incidence, and that children, under ten years of age, were the most affected strata of the population. Although no natural infection was found in sand flies, Lutzomyia longipalpis was recognized as the only vector, based in the fact that this was the predominant anthropophilic sand fly species in the areas surveyed and it was readily infected after being fed on an infected dog (Amaral et al., 1961d). Only the dog has been shown to be the reservoir of AVL in Venezuela (Torrealba et al., 1961; Torrealba, 1970). No sylvatic reservoirs have been reported, although a systematic search for Leishmania spp. infection has been carried out in over two hun- 
dred feral animals, including 50 foxes (Cerdocyon thous) (Torrealba \& Torrealba, 1964). Up to 1995, a total of 818 human cases of AVL have been registered in 18 of the 23 states of Venezuela, most of these cases ( $45 \%$ ) being recorded from the eastern state of Sucre (Files of the Department of Dermatology, Caracas). However. because of the difficulty of differential diagnosis with other endemicities in rural areas, many cases go unreported. Therefore the true incidence may actually be higher than the figures reported in official statistics.

In Aragua state AVL is endemic (33 cases between 1955 and 1995). In the village Guayabita since the first human case described by Pifano (1969), no others have been clinically detected until the case we reporte here. During the last 30 years no canine AVL has been registered, nor have there been any studies carried out on human or canine immunogical status. This paper deals with the human and canine infection patterns among inhabitants and dogs of this old focus where AVL seems to be re-emerging.

\section{MATERIALS AND METHODS}

\section{STUDY AREA}

The village Guayabita $\left(10^{\circ} 16^{\prime} \mathrm{N}, 67^{\circ} 28^{\prime} \mathrm{W}\right.$; $500 \mathrm{~m}$ above sea level) is located in the valley of Aragua State, in north-central Venezuela (Fig. 1), at the foothill of the Cordillera de la Costa (Costal Mountain Range). Based on the climate and the vegetation, Ewel \& Madriz (1968) defined this life zone as premontane dry forest. The climate is markedly seasonal with six months of dry weather (November-April), an annual mean temperature of $25^{\circ} \mathrm{C}$ and an average annual precipitation of $850-1000 \mathrm{~mm}$. Guayabita is $\cong 20 \mathrm{~km}$ from Maracay.

\section{CASE REPORT}

The patient, L. C., a 27 years old male from Guayabita was examined by one of us (J.A.) at the Central Hospital in Maracay in April 1992. He presented the classical signs and symptoms of AVL, including prolonged fever, hepato-splenomegaly $\left(4 / 4^{\circ}\right)$, intense paleness and complained of continuous loss of weight during the previous five months. He was referred to the Laboratory of Inmunoparasitology of the Instituto de Medicina Tropical, Caracas, with a presumptive diagnosis of AVL. Formolgelification (FG), inmunofluorescent antibody (IFAT), counter-inmuno-electroforesis (CIEP) and Western Blot (WB) were carried out according to the methodology described below.

\section{SURVEY FOR HUMAN INFECTION}

For a demographic survey, several visits were made at the village of Guayabita and a map of the locality was

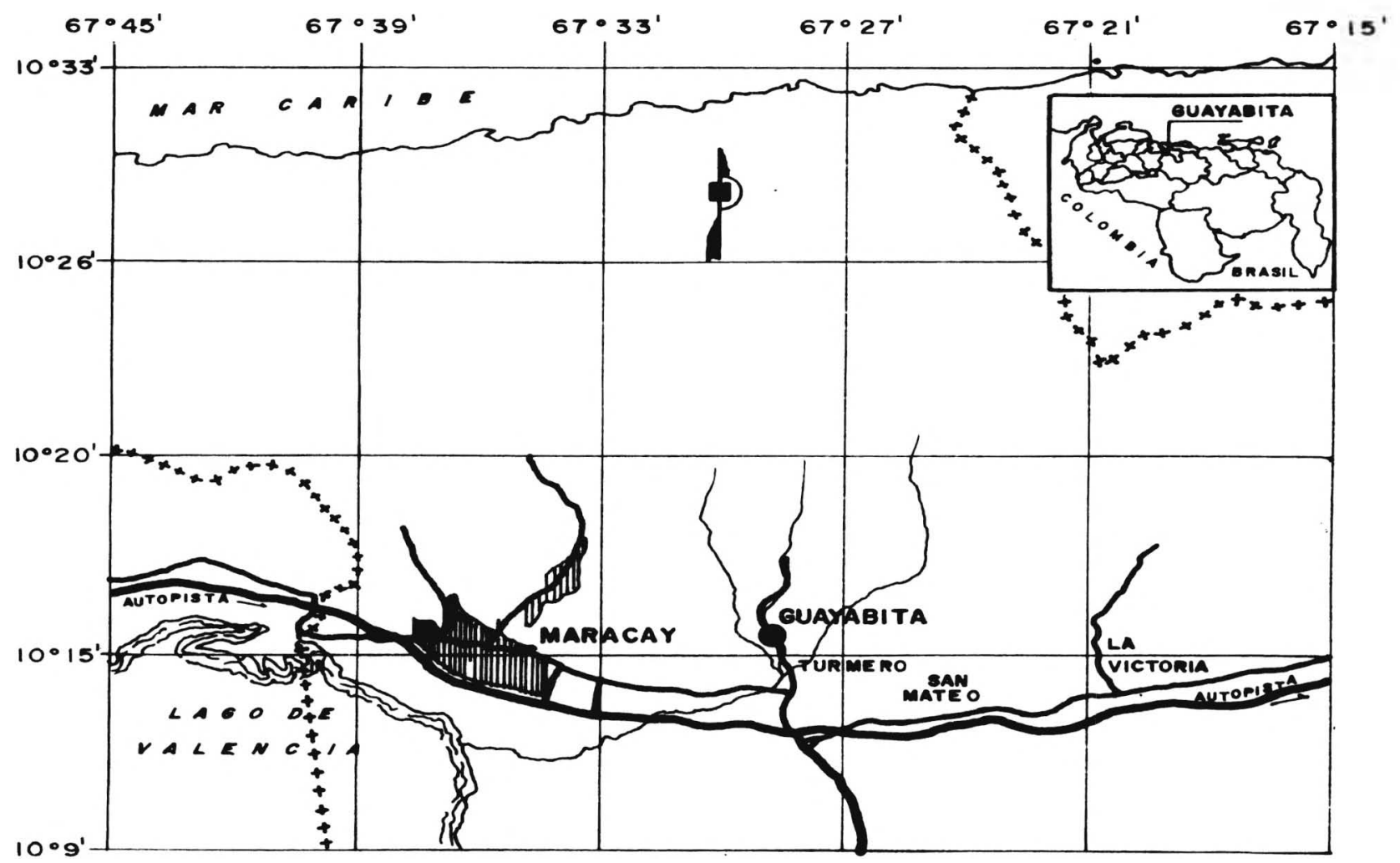

Fig. 1. - Map showing the location of the village Guayabita, Aragua State, Venezuela. 
prepared. The inhabitants were gathered at the primary school where they were informed about the disease and the purpose of the study. Afterwards, with the aid of medical students, a census was made visiting each household and recording names, sex and age of all family members. Additionally, a structured questionnaire was used on $26(40 \%)$ of the of 65 families, in which data regarding occupation, length of residence in the area and migratory history was collected. A cross-sectional study using leishmanin skin test (LST) and other serological tests, was carried out to examine the magnitude of sero-conversion among the population. Children under one year were excluded from the study. The leishmanin test was applied to 315 (58.8\%) individuals and venous blood samples for CIEP were obtained from those present in the houses at the moment of the visit $(n=320)$, which represented $65 \%$ of the total population. IFAT was performed on 191 $(38.7 \%)$ of the samples.

\section{SURVEY FOR CANINE INFECTION}

The total canine population was also studied in Guayabita and blood samples were collected by jugular vein puncture after immobilization and sedation with Combelen. The active ingredient of this drug is chlorpromazine which produces muscular relaxation and sedation. Parasite isolation was attempted in dogs with positive reaction to $\mathrm{FG}$, using bone marrow puncture and culture in blood-agar medium. Dog sera were screened with counter immuno-electrophoresis. Dogs that were positive by both of these methods were subjected to IFAT and Western Blot.

\section{PARASITOLOGICAL AND SEROLOGICAL METHODS}

Formolgelification test, employed to test the disproteinoemia in patient and canine sera, were performed as described by Gutman et al., 1937. Leishmanin skin testing and detection of anti-Leishmania antibodies was carried out according to the following procedure:

Leishmanin skin testing

The antigen was prepared from a pool of Leishmania spp., grown during eight days in agar blood medium, washed in PBS $0.02 \mathrm{M}, \mathrm{pH}=7.4$ and resuspended in physiological saline containing $0.5 \%$ phenol at concentration of $1.5 \times 10^{6}$ promastigotes $/ \mathrm{ml}$. This antigen was stored at $4{ }^{\circ} \mathrm{C}$ until use. Both, antigen and control material (physiological saline containing 0.5\% of phenol), were administrated in a dose of $0.1 \mathrm{ml}$. intradermally on the volar surface of both forearms and reading was done after $48-72$ hours, using the ball-point pen method. The test was considered as positive when an induration $\geq 5 \mathrm{~mm}$ was observed (Sokal, 1975; Ali \& Ashford 1993a; Shiddo et al., 1995; W.H.O., 1996).
Immunofluorescent antibodies test

The antigen was prepared using whole promastigotes of an isolate of Leishmania sp. from a patient with American visceral leishmaniasis proceeding from the locality of Chuao, Aragua Sate ( $25 \mathrm{~km}$ from Guayabita), according to the technique described by Pappas et al. (1983). A reaction was considered positive when more than $50 \%$ of the organisms showed complete peripheral fluorescence (titers $\geq 1: 32$ ).

\section{Counter immunoelectrophoresis}

The antigen was prepared from the same parasite mentioned above and the soluble antigen was prepared according to Bray et al. (1973). The method of Bussard (1959), modified by Delgado et al., (1978) was employed.

\section{Western Blot}

This technique was employed for the follow-up of the case and to his family members since they were considered as the group of greatest risk of infection in the area. The Leishmania antigen was separated by electrophoresis on $12 \%$ SDS PAGE (sodium duodecyl sulfate/polyacrilamide gel electrophoresis) under reducing conditions. The gels were electroblotted (Towbin et al., 1979) onto nitrocellulose sheets and blocked in $2 \%$ skimmed milk solution at room temperature with the respective sera in a 1:100 dilution in PBS containing $0.05 \%$ Tween 20 . After three washes, the strips were incubated for one hour with peroxidase conjugated anti-human IgG at an optimal dilution of 1:1000 in PBS, washed again three times and developed on Kodak film using peroxidase chemoluminescent substrate (Amersham ECL detection system).

\section{DATA ANALYSIS}

Data analysis was performed using Epi info-6.04b.

\section{RESULTS}

\section{HUMAN LEISHMANIASIS CASE FOLLOW-UP}

The formolgelification test was suggestive of AVL, being positive after 30 minutes. The CIEP test showed three clear precipitation bands of antigen-antibody complex. The IFAT test was highly positive with a title $>$ of 1:256. Elevated inmune response against the parasite was also demonstrated by the Western blot analysis. A banding pattern which comprised proteins of molecular weight between 36 and $68 \mathrm{kDa}$, which agreed with a positive control pattern and were not present in a negative control, is shown in Figure 2 (line 1).

After the diagnosis (09/04/1992), the patient received a first series of daily injections of $\mathrm{N}$-methyl glucamine 


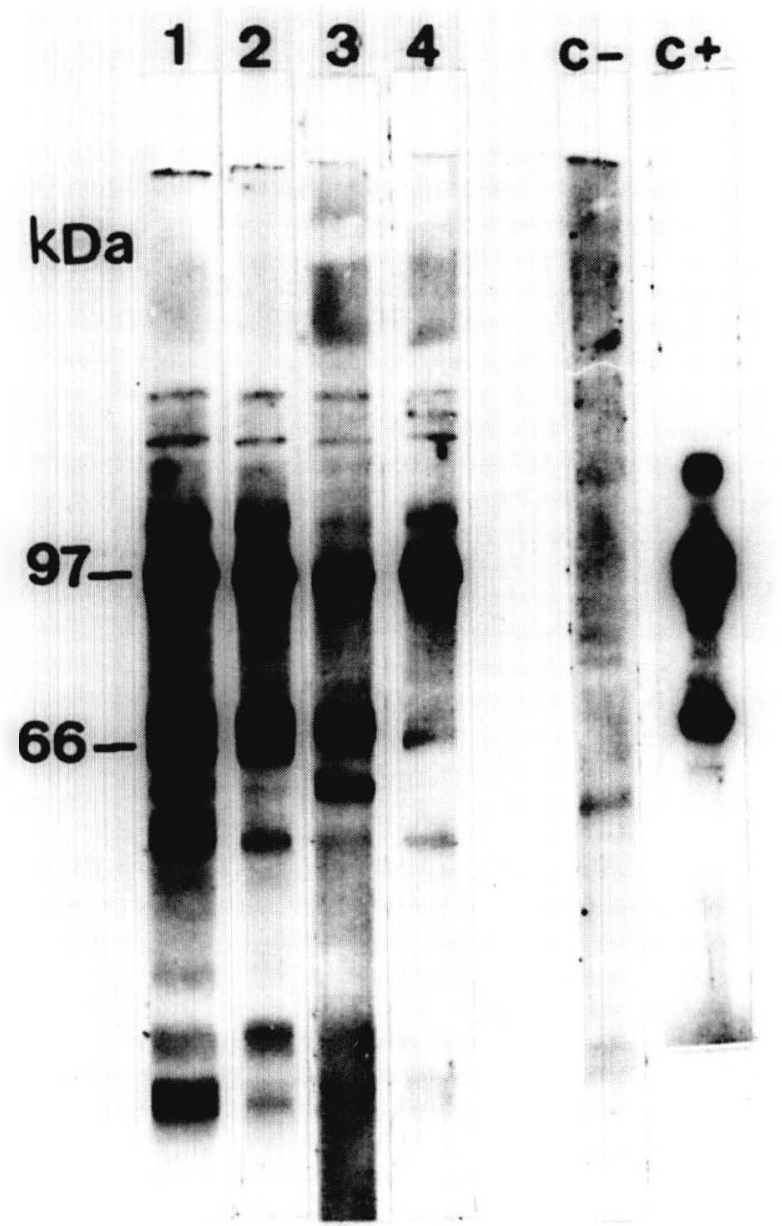

Fig. 2. - Follow-up of the LV case detected in 1992 in Guayabita by Western blot: before treatment (1); August 1992 (2); June 1994 (3); June 1997 (4); $\mathrm{C}^{-}$negative control; $\mathrm{C}^{+}$positive control.

antimoniate (Glucantime ${ }^{R}$; Specia, Paris, France) for 15 days, at a dosage of $30 \mathrm{mg}$ of antimony $/ \mathrm{kg}$ of body weight, to reach 21 gr. Following a 20-day rest period, a second round of antimony at the same dose for 20 days was appplied. Although the clinical evolution was satisfactory, splenomegaly persisted, therefore ten days later, a third similar series of Glucantime was given during ten days to reach a total of 66 gr of antimony. The IFAT, CIEP and the Western blot were repeated every four months in 1992 (August and December) and every six months until June 1994. Last analysis were made in June 1997. At this time the IFAT and CIEP were negative, while the WB still remained reactive, but the $\mathrm{Mr} 66 \mathrm{kDa}$ antigen was not recognized.

\section{DEMOGRAPHIC DATA}

The census study recorded a total population of 493 inhabitants, 246 males and 247 females, living in

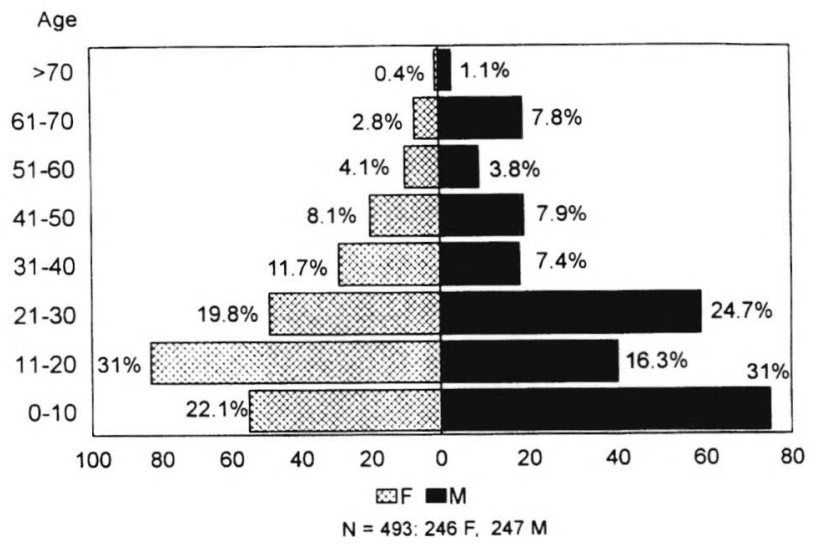

Fig. 3. - Age and sex distribution of the inhabitants of the village Guayabita, Aragua State, Venezuela.

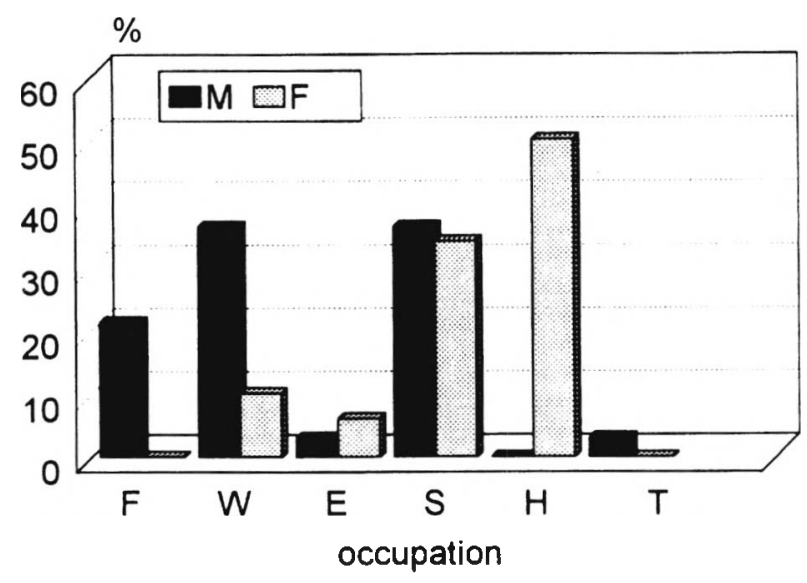

$F=$ farmers; $W=$ workers; $E=$ employers $S=$ students; $H=$ housewives; $T=$ traders

Fig. 4. - Occupation and sex distribution of the inhabitants of the village Guayabita, Aragua State, Venezuela.

65 households. Family size varied between one and 23 , with seven being the median number of household members. Figure 3 shows the age structure of the population at risk by age and sex: $24.5 \%$ of the inhabitants were under ten years of age and $46.9 \%$ were under 20 years. Figure 4 shows the distribution by occupation and sex in a sample of 135 individuals of 26 families (26\%).

Reactivity of the leishmanin skin test

A total of $315(63.9 \%)$ individuals consented to be skintested ( $42.2 \%$ males and $57.8 \%$ females). The global prevalence was $11.4 \%$. Twenty one of the males $(15.8 \%)$ and 15 of the females $(8.2 \%)$ were positive, with an induration of $5 \mathrm{~mm}$ after $48-72 \mathrm{hs}$. The difference between sexes was significant (Odds ratio $=2.09$; 
$95 \% \mathrm{CL}=0.97<\mathrm{OR}<4.50 ; \chi^{2}=4.32 ; \mathrm{df}=1 ; \mathrm{P}=$ 0.03757). Thirty-three other individuals showed indurations ranging from $1 \mathrm{~mm}$ to $4 \mathrm{~mm}$. Skin test positivity increased with age, being significantly different among the various age groups (Fig. 5) $\left(\chi^{2}=23.28 \mathrm{df}\right.$ $=6 ; \mathrm{P}=0.0007)$. However, when the leishmanin positive villagers were examined by age and sex, no significant difference was found among females by age $\left(\chi^{2}\right.$ $=9.19 \mathrm{df}=6 ; \mathrm{P}=0.16)$ while skin test positivity suggests greatest infection among males over 20 years of age, $\left(\chi^{2}=20.03 \mathrm{df}=6 ; \mathrm{P}=0.002\right)$. Among 83 skin tested subjects for whom occupation was known, a significant high proportion of workers was leishmanin positive (Fig. 6) (Odds ratio $=7.13 ; 1.89<\mathrm{OR}<27.81$; $\left.\chi^{2}=12.3 \mathrm{df}=5 ; \mathrm{P}=0.0004538\right)$. However, as for age, the significance was observed among males $\left(\chi^{2}=\right.$

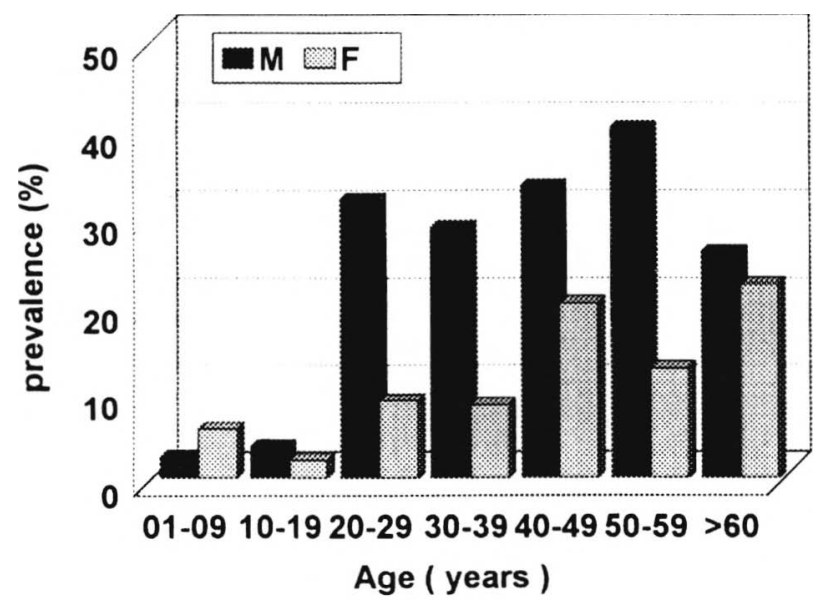

Fig. 5. - Age and sex distribution of leishmanin positive inhabitants of the village Guayabita, Aragua State, Venezuela.

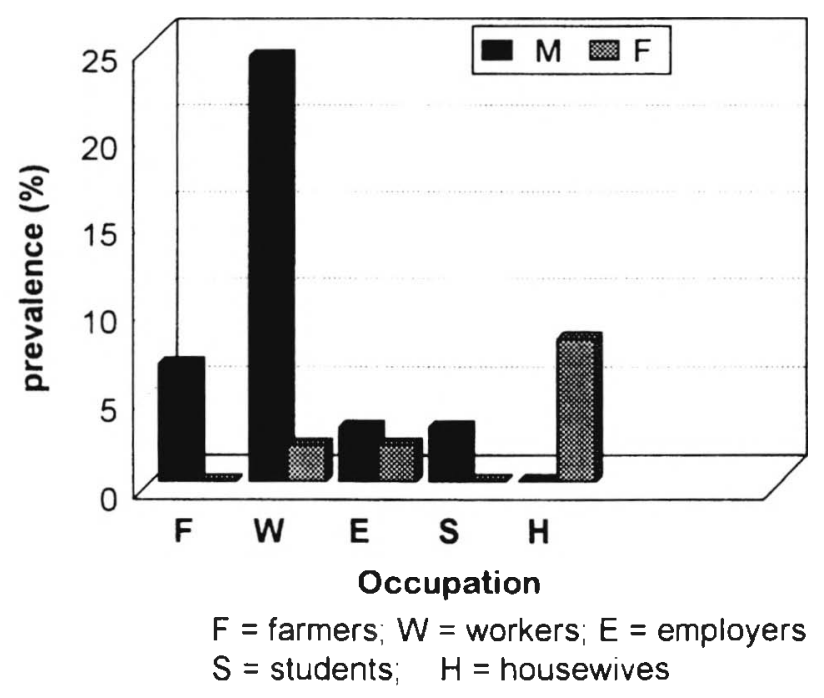

Fig. 6. - Occupation and sex distribution of leishmanin positive inhabitants of the village Guayabita, Aragua State, Venezuela.
$11.34 \mathrm{df}=5 ; \mathrm{P}=0.00045)$ but not among females $\left(\chi^{2}\right.$ $=11.34 \mathrm{df}=5 ; \mathrm{P}=0.00045)$. No correlation was found between the time of residence in the village and the positivity to leishmanin skin-test among 24 of the 36 positive individuals with anamnesis history.

\section{SEROPREVALENCE TO SPECIFIC ANTIBODIES}

A total of 320 individuals, which included all leishmanin positive, agreed to give blood for serological examination. All were tested for CIEP $(70.6 \%$ of the population) and $191(38.8 \%)$ were also tested for IFAT. Ten individuals $(2.8 \%)$ were reactive for CIEP and two $(1.05 \%)$ had an IFAT titer 1:128. One of these was the case and the other was an 84 year old man. Additionally, six individuals (3.1\%) reacted with titers of $1: 32$ (our threshold value) and seven (3.7\%) with titers of $1: 16$.

No significant differences were found among seroreactors of different age-classes or occupations. Concordance was not found when comparing reactivity between the three tests used. Only two individuals with anti-Leishmania antibodies, as detected by CIEP and one with anti-Leismania antibodies detected by IFAT, were also leishmanin positive.

\section{CANINE LEISHMANIASIS}

A total of 71 dogs were examined. Amastigotes were found in the bone marrow smear of only one dog. Six ( $8.5 \%)$ were sero-positive to FG and 11 (15.5\%) were sero-reactive with CIEP. These included those that had sera positive to FG. Four of these $(5.6 \%$ of the total) were also IFAT positive (titer $=1: 64$ ) and Western Blot positive. No association was found between seroreactive humans and seroreactive or parasitologically positive dogs in the same house, neither among human and canine population clustered per each five houses to gauge the risk to the human members posed by the presence of a positive dog in their or neighbouring houses.

\section{DISCUSSION}

he appearance of an autocthonous clinical case
of American visceral leishmaniasis, a parasito-
logically infected dog, as well as many seropositive persons and dogs in the village of Guayabita, after 30 years of epidemiological silence, suggest the re-emergence of this disease in this focus. This is consistent with what has been reported in other areas of Venezuela (Aguilar et al., 1998) and Brazil (Arias et al., 1996), where AVL is becoming an urban and periurban problem. The humoral immune response detected through CIEP and IFAT (titers 1:32) as well as the positive LST, is also suggestive of the fact that 
the parasite is circulating among inhabitants, in which, in most cases, the infections appear to be sub-clinical. The significance of titers of 1:16, in an area where other diseases which may produce cross-reactions (such as Chagas Disease or Malaria) are not present, remains to be determined. These may represent recent (subclinical) infections.

The prevalence of AVL among the population, as measured by the specific cell mediated response (LST) was of $11.4 \%$. The significance of the leishmanin reaction has been reviewed by Ali \& Ashford (1993a), which has been used as an epidemiological tool in AVL studies. These authors have noted that the LST becomes positive about one year after infection (and cure) of American Visceral Leishmaniasis, thus detecting past, self healing, infections. Southgate $\&$ MansonBarr (1967) and Pampiglione et al. (1975) illustrated the potential of the leishmanin test to indicate subclinical (cryptic) infections which increases with age (Badaró et al., 1986, Corredor et al., 1989; Ali \& Asford, 1993a).

In Guayabita the LST increases with age, and it appears to be linked to the gender. Young males seem to be more exposed to infection than females. Since occupation per se does not seem to account for this situation, this fact may be explained with gender-associated behavior leading to different degrees of exposure to sand flies. Men remain outside more than women until late hours when sand flies are actively searching for blood meal. The presence of infected females has already been detected in this locality (Feliciangeli et al. 1993). The fact that the prevalence of infection in dogs was not related to human cases in Guayabita, as observed elsewhere (Evans et al., 1992; Rab et al., 1995), is also suggestive that disease transmission is mainly related to human behavior associated with vector bionomics, than to the presence of infected dogs. Probably for this reason, the clustering of leishmanin positivity in household contacts related before (Pampiglione et al., 1975; Ashford \& Smith, 1985; Badaró et al., 1986; Nandy et al., 1987; Ali \& Ashford, 1993b) was not consistent in Guayabita.

Seeing that the LST may convert after AVL cure (Ali \& Ashford, 1993b), the usefulness of this test in crosssectional surveys in different foci, is to be recommended to update and understand the epidemiological situation of the American visceral leishmaniasis.

\section{ACKNOWLEDGEMENTS}

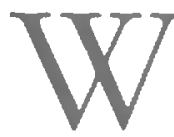

e are grateful to the residents of Guayabita for their cooperation. Thanks are due to Maria Martinez de Pena, Iris Fernandez and Nancy Bastidas, staff of the University of Carabobo, to medical and bioanalist students of 1994 course for their help in the field work and Silvia Silva and Virginia Coraspe, staff of the Instituto de Medicina Tropical for their help in the laboratory work. Freddy Arias and Florencio Mendoza are acknowledged for their technical assistance. We also thank Jorge Arias for the critical revision of the manuscript. This work was supported by grants from CONICIT (RP-IV-130034), FUNDACITE Aragua (Pasa-17) and the University of Carabobo (CODECIHT-91-044).

\section{REFERENCES}

Aguilar C.M., Fernandez E., Fernandez R., Cannova D.C., Ferrer E., Cabrera Z., Souza W.J.S. \& Coutthho S.G. Urban visceral leishmaniasis in Venezuela. Memorias do Instituto Oswaldo Cruz, 1998, 93, 15-16.

Al A. \& Ashford R.W. Visceral leishmaniasis in Ethiopia. I. Cross-sectional leishmanin skin test in an endemic locality. Annals of Tropical Medicine and Parasitology, 1993a, 87, 157-161.

Ali A. \& AshForn R.W. Visceral leishmaniasis in Ethiopia. II. Annual leishmanin transformation in a population. Is positive leishmanin reaction a life-long phenomenon? Annals of Tropical Medicine and Parasitology, 1993b, 87, 157-161.

amaral A.D.F., Torrealiba J.W., Henriquez C.E., Kowalenko W. \& Barrios P.A. Studies on visceral leishmaniasis in Venezuela. Revista do Instituto de Medicina tropical de Sâo Paulo, 1661a, 3, 91-98.

amaral A.D.F., Torrealba J.W., Henriquez C.E., Kowalenko W. \& Barrios P.A. Revision sobre el kala-azar en Venezuela. Folia Clinica Biologica, 1961b, 30, 14-24.

amaral A.D.F., Torrealia J.W., Henriguez C.E., Kowalenko W. \& Barrios P.A. Consideraciones sobre el kala-azar en el mundo y su presencia comprobada en Venezuela desde 1941. Revista Venezolana de Sanidad y Asistencia Social, 1961c, 26, 350-356.

amaral A.D.F., Torrealba J.W., Henriquez C.E., Kowalenko W. \& Barrios P.A. Phlebotomus longipalpis Lutz \& Neiva, 1912, probable transmisor de la lesihmaniasis visceral en Venezuela. Gaceta Médica de Caracas, 1961d, 70, 389-408.

ARIAS J.R., MonTEIRO P.S., Zickrr F. The re-emergence of visceral leishmaniasis in Brazil. Emerging Infectious Diseases, $1996,2,145-146$.

Ashford R.W. \& SMith D.H. Leishmaniasis in Sudan, Ethiopia and Kenya. In: Human Parasitic Diseases. Vol. 1, Chang K.P. \& Bray R.S. (eds) Amsterdam, Elsevier, 1985, 377-391.

Badaro B., Jones T.C., Lorenço R., Cerf B.J., Sampaio D., Carvalho E.M., Rocha R., Teixeira R. \& JOHnSON W.D. A prospective study of visceral leishmaniasis in an enclemic area of Brasil. The Journal of infectious diseases, 1986, 154, 639649.

Bray R.S., Ashford R.W., Muherfeld A.M. \& Sen Gupta P.C. Studies on the inmunology and serology of the leishmaniasis. Transactions of the Royal Society of Tropical Medicine and Hygiene, 1973, 67, 125- 129. 
Bussard A. Description d'une technique combinant simultanément l'électrosynérèse. Biocbemica et Biophisica Acta $1959,34,258-260$.

Corredor A., Gallego J.F., Tesh R., Morales A., Ferro de Carrasquilla C., Young D., Kreutzer R.D., Bishell J., Palau M.T., Caceres E. \& Pelaez D. Epidemiology of visceral leishmaniasis in Colombia. American Journal of Tropical Medicine and Hygiene, 1989, 40, 480-486.

Delgado O., Orihuela R., Garcia L., Scorza J.V., Simonovic E., Silva S. \& Mattei R. Especificidad y sensibilidad de las técnicas de inmunoelectroforesis e inmuno-fluorescencia indirecta en el diagnóstico de la leishmaniasis visceral. Boletin Venezolano de Infectologia, 1978, 3, 13-16.

Evans T.G., Teixiera J.M., McAullife I.T., Vasconcelos J.A.B., Vasconcelos A.W., Sousa, A.Q., Lima J. W.O. \& Pearson R.G Epidemiology of visceral leishmaniasis in northeast Brazil. Journal of Infectious Diseases, 1992, 166, 1124-1132.

EwEl, J. J. \& MADriz A. Zonas de vida de Venezuela. Memoria explicativa sobre el mapa ecológico. Editorial Sucre, Caracas. 1968, 264.

Filiciangeli M.D., Gomez B., Delgado O., Garcia L. \& Bello C. Leishmaniasis visceral en el caserio La Ganaderia de Guayabita, estado Aragua, Venezuela. Infección natural de Lutzomyia evansi (Diptera: Psychodidae) a Leishmania spp. Acta Científica Venezonala, 1993, 44 (Suppl. 1), 262.

Gutman B., Alexander E., \& Wise R. Positive formol-gel reaction associated with hyperglobulinemia in lymphogranuloma inguinale, multiple myeloma and hepatic cirrhosis. Proceedings of the Society of Experimental Biology and Medicine, 1937, 35, 124-128.

Martinez Niochet A. \& Pons A.R. Primer caso de kala-azar en Venezuela. Gaceta Médica de Caracas, 1941, 48, 329332.

Nandy A., Neogy A.A. \& Chowdhury A.B. Leishmanin test survey in an endemic village of Indian Kala-azar near Calcutta. Annals of Tropical Medicine and Parasitology, 1987, 81, 693-699

Pampiglione S., Manson-Bahr P.E.C., La Placa M., Borgatti M. \& Mutdumeci S. Studies on Mediterranean leishmaniasis. 3. The leishmanin skin test in kala-azar. Transactions of the Royal Society of Tropical Medicine E Hygiene, 1975, 69, 60-68.

Pappas M.G., MC Greevy P.B., Hajkowski R., Hendricks L.D., OSTER C.N. \& HoCKMEYER W.T. Evaluation of promastigote and amastigote antigens in the indirect fluorescent antibody test for American cutaneous leishmaniasis. American Journal of Tropical Medicine and Hygiene, 1983, 32, 12601267.

PIfano F. Estado actual del kala-azar ern Venezuela. Archivos Venezolanos de Patología Tropical y Parasitologia Médica, 1954, 2, 213-219.

Pifano F. \& Romfro M.J. Investigaciones epidemiológicas sobre la leishmaniasis visceral en la Isla de Margarita, Edo. Nueva Esparta, Venezuela. Gaceta Médica de Caracas, $1964 a, 72,425-430$.

Pifano F. \& Romero M.J. Comprobación de un nuevo foco de leishmaniasis visceral en Venezuela, Valle de Cumanacoa, Edo. Sucre. Gaceta Médica de Caracas, 1964b, 72, 473-479.
Pifano F. Algunos aspectos en la ecologia y epidemiología de las enfermedades endémicas con focos naturales en el área tropical, especialmente en Venezuela. Ministerio de Sanidad y Asistencia Social (ed) Caracas, 1969.

Rab M.A., Frame J.A., \& Evans D.A. The role of the dogs in the epidemiology of human visceral leishmaniasis in northen Pakistan. Transactions of the Royal Society of Tropical Medicine E Hygiene, 1995, 89, 612-615.

Shiddo S.A., Aden Mohamedd A., Akuffo H.O., Herzi A.A., Haji Mohamed H., Huldt G., Nilsson l.A., Ouchterlony O. \& Thorstensson R. Visceral leishmaniasis in Somalia: prevalence of markers of infection and disease manifestations in a village in an endemic area. Transactions of the Royal Society of Tropical Medicine E Hygiene, 1995, 89, 361-368.

SOKAL J.E. Measurement of delayed skin-test responses. New England Journal of Medicine, 1975, 293, 501-502.

Southgate B.A. \& Manson-Barr P.E.C. Studies on the epidemiology of East African leishmaniasis. 4. The significance of the positive leishmanin test. Journal of Tropical Medicine and Hygiene, 1967, 70, 29-33.

Torrealba J.W., Amaral A.D.F., Henriquez C.E., Kowalenko W. \& Barrios P.A. Observaciones iniciales sobre el perro (Canis familiaris) como reservorio de kala-azar en Venezuela. Revista de Sanidad y Asistencia Social, 1961, 26, 342349 .

Torrealba J.W. \& Torrealba J.F. Infección experimental de Cerdocyon thous (zorro común) con Leishmania donovani. Gaceta Médica de Caracas, 1964, 72, 17-18.

TORREAlBA J.W. Observaciones sobre diagnóstico, terapéutica y evolución de la leisbmaniasis bumana y canina. Thesis, Valencia, 1970, $367 \mathrm{pp}$.

Towisin H., STaehelin T. \& GoRdon J. Electrophoretic transfer of proteins from polyacrylamide gels to nitrocellulose sheets: procedure and some applications. Proceedings of the National Academy of Science, USA, 1979, 76, 4350.

World HEALTH ORGanization. Manual of visceral leishmaniasis. 1996. WHO/LEISH/96.40.

Reçu le 19 décembre 1997 Accepté le 26 juin 1998 